\title{
Silver Nanoparticles as a New Generation of Antimicrobial Prophylaxis
}

\author{
Ilnur T. Garipova \\ Renat R. Khaydarov*a, Olga U. Gapurova ${ }^{a}$, \\ Rashid A. Khaydarov , M. Lutfi Firdaus ${ }^{\text {, }}$, \\ Irina L. Efimova ${ }^{c}$ and Svetlana Yu. Evgrafova ${ }^{\mathfrak{c}}$ \\ ${ }^{a}$ Institute of Nuclear Physics \\ Academy of Sciences of Republic of Uzbekistan \\ 1 Huroson, Ulugbek vil., Tashkent, 100214, Uzbekistan \\ ${ }^{b}$ University of Bengkulu \\ Jl. WR Supratman, Kandang Limun, Bengkulu, 38371, Indonesia \\ ${ }^{c} V . N$. Sukachev Institute of Forest SB RAS \\ FRC "Krasnoyarsk Science Center SB RAS" \\ 50/28 Akademgorodok, Krasnoyarsk, 660036, Russia
}

Received 28.02.2019, received in revised form 23.05.2019, accepted 26.06.2019

Over the last 20 years, metallic silver in the form of Ag nanoparticles has made a remarkable comeback as an example of a nanomaterial for control of microorganisms. The purpose of our study was a) to quantitatively estimate the antimicrobial effect of silver nanoparticles compared with that of silver ions and b) to check the efficacy of nanosilver as an antimicrobial agent against a range of microbes on the surface of water-soluble paint, 100\% cotton fabric, and fibrous chemisorbent. Minimum inhibitory concentration tests quantitatively showed that Ag nanoparticles were less efficient than $\mathrm{Ag}^{+}$ions against representatives of gram-positive / gram-negative bacteria and cosmopolitan saprotrophic fungi. Antifungal/antibacterial effects against Aspergillus niger, Penicillium phoeniceum, and Staphylococcus aureus were confirmed for nanosilver concentrations of even $1 \mu \mathrm{g} / \mathrm{cm}^{2}$ on the surface of cotton fabric and $0.8 \mu \mathrm{g} / \mathrm{cm}^{2}$ in water-soluble paint. As the concentration of nanosilver in watersoluble paint/cotton fabric was increased to $7 \mu \mathrm{g} / \mathrm{cm}^{2}$, the growth of Bacillus subtilis and Escherichia coli was suppressed as well. Microbiological tests conducted over a period of 60 days showed that there was no biofilm growth on the surface of a silver nanoparticle-coated fiber sorbent during its everyday operation as a household water treatment filter. Thus, silver nanoparticles as an add-on to water-soluble paints, textile fabrics or fiber chemisorbents had a remarkable antibacterial/antifungal effect, although some of the Ag nanoparticles were agglomerated into larger colloidal clusters.

(C) Siberian Federal University. All rights reserved

This work is licensed under a Creative Commons Attribution-NonCommercial 4.0 International License (CC BY-NC 4.0).

* Corresponding author E-mail address: renat@inp.uz ORCID: 0000-0001-9228-2727 (Khaydarov R.R.) 
Keywords: silver, nanoparticles, nanomaterial, fibrous sorbent, water treatment.

Citation: Garipov I.T., Khaydarov R.R.., Gapurova O.U., Khaydarov R.A., Firdaus M.L., Efimova I.L., Evgrafova S.Yu. Silver nanoparticles as a new generation of antimicrobial prophylaxis. J. Sib. Fed. Univ. Biol., 2019, 12(3), 266-276. DOI: 10.17516/1997$1389-0301$.

\title{
Наночастицы серебра -
}

\section{новое поколение антимикробной профилактики}

\author{
И.Т. Гарипова, Р.Р. Хайдаров \\ О.У. Гапурова ${ }^{a}$, Р.А. Хайдаров $^{a}$, \\ М.Л. Фирдаус ${ }^{\tilde{\sigma}}$ И.Л. Ефимова ${ }^{\mathrm{B}}$, С.Ю. Евграфова ${ }^{\mathrm{B}}$ \\ ${ }^{a}$ Институт ядерной физики АН РУ \\ Узбекистан, 100214, Ташкент, Улугбек, Хуросон, 1

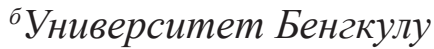 \\ Индонезия, 38371, Бенгкулу, Канданг Лимун, Дж. Вр. Супратман \\ ${ }^{8}$ Институт леса имени В.Н. Сукачева СО РАН \\ ФИЦ «Красноярский научный иентр СО РАН» \\ Россия, 660036, Красноярск, Академгородок, 50/28
}

В последние 20 лет наночастицы серебра (НC) намли широкое применение в качестве антимикробного средства. Но вследствие недостаточной изученности воздействия наноматериалов на живые организмы вопрос эффективности и безопасности НС до сих пор остается открытым. В иели наших исследований входила количественная оценка антимикробной способности НС в сравнении с ионами серебра, а также оценка антимикробной эффективности НС при введении его в водорастворимые краски, хлопчатобумажные ткани и волокнистые сорбенты. Оиенку проводили на основе стандартной методики определения минимальных ингибирующих концентраций. Результаты исследований для ряда грамположительных/грамотрицательных бактерий и сапротрофных грибов показали, что наночастищь серебра были менее эффективны по сравнению с ионами серебра. Тем не менее антигрибной и антибактериальный эффекты НС для культур A. niger, P. phoеniceuт u S. aureus проявлялись уже при концентрации наносеребра 1 мкг/см² на поверхности хлопчатобумажной

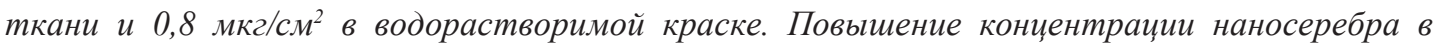
водорастворимой краске/хлопчатобумажной ткани до 7 мкг/см² обеспечивало также подавление pocта культур B. subtilis и E. coli. Было показано, что при 60-дневном систематическом использовании волокнистого сорбента, покрытого наночастицами серебра, в качестве бытового фильтра для очистки воды на нем не наблюдалось роста биопленок. Таким образом, наночастицы серебра в качестве добавки к водорастворимым краскам, текстильным тканям и волокнистым сорбентам обладают выраженным антибактериальным/противогрибковым эффектом, несмотря на наблюдающуюся тенденщию ряда наночастии серебра к агломерации в коллоидные кластеры. 
Ключевые слова: серебро, наночастииы, наноматериал, волокнистый сорбент, водоподготовка.

\section{Introduction}

Metallic silver has been known for its antibacterial and antifungal properties. In ancient Greece and Rome, silver was widely used to control infections and spoilage. Since the $20^{\text {th }}$ century, silver and its compounds have been used extensively in many bactericidal applications, including wound healing, water treatment, flower preservatives, etc. (Klasen, 2000). Over the last few decades, silver nanoparticles, defined as structures up to $100 \mathrm{~nm}$ in size, have been extensively investigated and found to have applications in catalysis (Lewis, 1993), optics (Murphy et al., 2005), electronics (Li et al., 2005), and other areas of science and technology (Niemeyer, 2001; Marambio-Jones and Hoek, 2010) due to their unique size-dependent optical, electrical, and magnetic properties (Oberdorster et al., 2005). Since 2000, most applications of silver nanoparticles have been related to their usage as antibacterial/antifungal agents (Morones et al., 2005; Buzea et al., 2007). Nanosilver application is one of the fastest growing product categories in the nanotechnology industry. For instance, there is a growing interest in the preparation of bactericidal cotton fibers containing silver nanoparticles for the textile industry (Lee and Jeong, 2004, 2005). Indeed, owing to their ability to retain moisture, ordinary cotton fabrics provide an excellent environment for microorganisms to thrive (Chen and Chiang, 2008). There is also a promising trend to impregnate commercially available paints with silver nanoparticles. For example, nanosilver-based wall paint would prevent the formation of mold inside buildings and the growth of algae on outside walls (Khaydarov et al., 2009a).

The lack of knowledge on the mechanism of the bactericidal effects of silver nanoparticles in combination with the significant growth of applications of nanosilver in various branches of industry over recent years has caused new concerns that silver nanoparticles may have a toxic effect on human health (Lok et al., 2007; Khalandi et al., 2017). In the $20^{\text {th }}$ century, a popular belief was that except for causing argyria, silver was relatively nontoxic to mammalian cells (Chen and Schluesener, 2008). However, studies conducted in recent decades (Soto et al., 2005; Braydich-Stolle et al., 2005; Hussain et al., 2005; Grodzik and Sawosz, 2006) have shown that at the nanoscale, silver-based materials can exhibit significant toxicity to animal and human cells. These issues must be addressed before people rush to indulge into the nanosilver boom (Chen and Schluesener, 2008).

The purpose of our study was a) to quantitatively estimate the antimicrobial effect of silver nanoparticles compared with that of silver ions and b) to check the efficacy of nanosilver as an antimicrobial agent against a range of microbes on the surface of paints, $100 \%$ cotton fabrics, and fibrous chemisorbent.

\section{Materials and methods}

\section{Preparation of Ag ions}

and nanoparticles

The process for producing silver nanoparticles was based on the use of an inexpensive two-electrode setup, in which the anode and the cathode are made from bulk Ag metal, which is to be transformed into Ag colloidal particles. We used two polished silver plates $(85 \mathrm{~mm} \times 20 \mathrm{~mm} \times 4 \mathrm{~mm})$ as the anode and the cathode, which were placed vertically face-to-face $10 \mathrm{~mm}$ apart. The electrodes were immersed in an electrochemical cell filled with $500 \mathrm{~mL}$ of distilled water obtained using an 
ordinary, commercially available water distiller (DE-25, Russia). Electrolysis was performed in the temperature range of $20-95^{\circ} \mathrm{C}$ at a constant voltage of $20 \mathrm{~V}$. The polarity of the direct current between the electrodes was changed every $30-$ $300 \mathrm{sec}$, and intensive stirring during the process of electrolysis was used to inhibit the formation of precipitates. Silver nanoparticle solutions produced in this way were stored under ambient conditions in glass containers (Khaydarov et al., 2004). The water-based silver colloidal solution was obtained by our three-stage process based on the electroreduction of silver ions in water (Khaydarov et al., 2009). The nanosilver particles produced were spherical, with a diameter of $7 \pm 3 \mathrm{~nm}$ (Fig. 1). The simplicity of this synthesis route allows low-cost fabrication of large amounts of long-lived silver nanoparticles. No chemical stabilizing agents are generally required, which expands the technological viability of the process and industrial applications of the method.

The concentrations of silver nanoparticles and ions in solutions were determined by neutron activation analysis (NAA) (Soete et al., 1972). Samples were irradiated in the nuclear reactor of the Institute of Nuclear Physics (Tashkent, Uzbekistan). The product of the nuclear reaction ${ }^{109} \mathrm{Ag}(\mathrm{n}, \gamma) \rightarrow{ }^{110} \mathrm{mAg}$ has a half-life $\left(\mathrm{T}_{1 / 2}\right)=253$ days.
The silver concentration was determined through measurements of the intensity of gamma radiation with an energy of $0.657 \mathrm{MeV}$ and 0.884 $\mathrm{MeV}$ emitted by ${ }^{110} \mathrm{mAg}$. A Ge(Li) detector with a resolution of approximately $1.9 \mathrm{keV}$ at 1.33 $\mathrm{MeV}$ and a 6144-channel analyzer were used for recording gamma-ray quanta.

The morphology of silver nanoparticles on the surface of cotton and paint samples was observed by field emission scanning electron microscopy (FE-SEM; JSM-6700F, JEOL, Japan). The size and shape of the nanoparticles in solution were determined by transmission electron microscopy (TEM) (LEO-912-OMEGA, Carl Zeiss, Germany).

\section{Antimicrobial activity assay}

To evaluate the antibacterial and fungicidal properties of silver particles, Escherichia coli was used as a representative gram-negative bacterium; Staphylococcus aureus and Bacillus subtilis were used as gram-positive bacteria; and Aspergillus niger, Aureobasidium pullulans and Penicillium phoeniceum were used to represent cosmopolitan saprotrophic fungi. The minimum inhibitory concentrations (MICs) of solutions for various microbes were determined using the microdilution broth susceptibility test. Nutrient
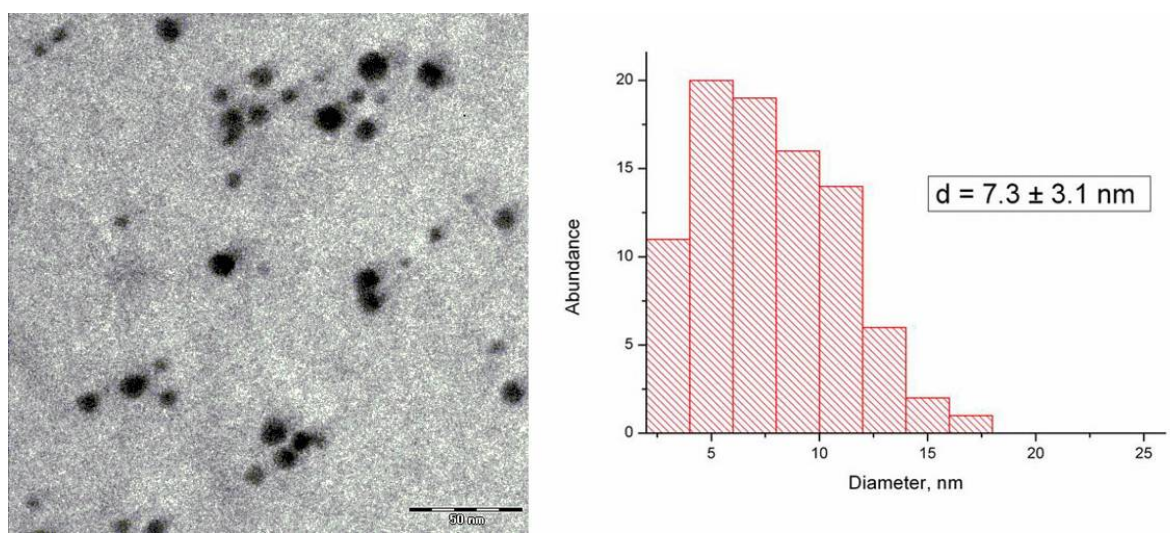

Fig. 1. A typical TEM micrograph (scale of $50 \mathrm{~nm}$ ) and a size distribution histogram for silver nanoparticles prepared by the electrochemical method 
broth used in the microdilution method contained peptic digest of animal tissue $(50.00 \mathrm{~g} / \mathrm{L})$, beef extract (1.5 g/L), sodium chloride (5.00 g/L), and glucose $(5 \mathrm{~g} / \mathrm{L})$ at $\mathrm{pH} 7.4 \pm 0.2$. A standardized suspension of approximately $10^{6}$ colony-forming units $(\mathrm{CFU}) / \mathrm{mL}$ density was obtained by inoculating the culture in nutrient broth (HiMedia) and incubating the tubes at $37^{\circ} \mathrm{C}$ for $3 \mathrm{~h}$. Serial dilutions of the dispersion of $\mathrm{Ag}$ ions and the dispersion of silver nanoparticles were prepared within a desired range. Ten milliliters of the standardized culture suspension was then inoculated, and tubes were incubated at $37^{\circ} \mathrm{C}$ for $24 \mathrm{~h}$. The MIC was defined as the lowest concentration of the inhibiting agent that completely inhibited bacterial growth, and the unit for the MIC was chosen as $\mathrm{mg}(\mathrm{Ag}) / \mathrm{L}$. The MIC was examined visually by checking the turbidity of the tubes.

\section{Antimicrobial finishing \\ of cotton and paint samples}

Common household acrylic paint widely used for renovating and decorating purposes was investigated. Silver nanoparticle-containing acrylic paint was obtained by diluting the initial paint sample with the $\mathrm{Ag}$ colloidal solution to achieve the desired nanosilver concentration within the desirable testing range of 2-50 ppm. For the antibacterial tests, a $22 \mathrm{~mm} \times 22 \mathrm{~mm}$ pasteboard was covered with silver nanoparticlecontaining acrylic paint.

Bleached woven cotton fabric weighing $98 \mathrm{~g} / \mathrm{m}^{2}$ was cut into equal-sized square pieces measuring $15 \mathrm{~mm}$ x $15 \mathrm{~mm}$. The samples were immersed in a colloidal solution bath for 1 minute and squeezed thoroughly, with further drying at $60^{\circ} \mathrm{C}$ for 5 minutes.

To evaluate the antibacterial and fungicidal properties of Ag nanoparticles added to a cotton fabric and an acrylic paint, samples with different $\mathrm{Ag}$ nanoparticle contents, as well as control samples, were immersed in a thin layer of beefextract agar. One milliliter of a suspension with an approximately $10^{5} \mathrm{CFU} / \mathrm{mL}$ density of the microorganisms to be tested was distributed uniformly on an agar surface and incubated at $28^{\circ} \mathrm{C}$. Antimicrobial activity was evaluated according to the presence or absence of microbial growth just above the sample after a 24-h incubation for bacteria and a 72-h incubation for fungi. All microbiological tests were performed in triplicate.

\section{Preparation of fiber sorbents}

Polyacrylonitrile (PAN) cloth with a surface density of $1.0 \mathrm{~kg} / \mathrm{m}^{2}$ and thickness of $10 \mathrm{~mm}$ was used as the raw material for making ion-exchange sorbents. The cation-exchange fiber sorbents were obtained by treatment of PAN cloth with a $20 \%$ $\mathrm{NH}_{2} \mathrm{NH}_{2} \cdot \mathrm{H}_{2} \mathrm{O}$ solution at $70^{\circ} \mathrm{C}$ for 30 minutes and with a $5 \%$ solution of $\mathrm{NaOH}$ at $25-30^{\circ} \mathrm{C}$ for one hour (Khaydarov and Khaydarov, 2006). We impregnated fibrous sorbents with our nanosized silver colloids by a method analogous to the technique used by Lee and Jeong (2005) for treating textile fabrics. The morphology of silver nanoparticles and silver-based sorbents was studied using TEM measurements. The concentration of silver nanoparticles was determined by neutron activation analysis (NAA) (Soete et al., 1972).

To evaluate the antibacterial and fungicidal properties of the sorbents modified with the nanosilver, we carried out the same microbiological procedures described above for cotton fabric samples.

\section{Results and discussion}

\section{Minimum inhibitory concentration assays}

The minimum inhibitory concentration (MIC) assays were conducted for electrically generated silver ions and silver nanoparticles using the gram-negative bacterium E. coli, gram- 
positive bacteria $S$. aureus and B. subtilis, and fungus $P$. phoeniceum (see Table 1).

For an adequate interpretation of the results obtained, one needs to consider that in the case of silver nanoparticles, there is a combination of effects, including (i) that associated with $\mathrm{Ag}$ ions released from the nanoparticles and (ii) that of direct interaction of cells with nanoparticles (Wang et al., 2015). The purpose of our nanosilver MIC assay was not to reveal which of the effects prevails but was to quantitatively estimate the combined antimicrobial efficiency of nanosilver. Thus, to inhibit the growth of gram-positive and gram-negative bacteria and fungi (Table 1), it was necessary to apply higher concentrations of nanosilver than the concentration of electrically generated silver ions. Despite the pronounced antimicrobial effect, silver ions have only limited use as antimicrobial agents in applications such as medical products, clothing, and household articles. This fact is due to their rapid binding or inactivation by various substances present in a medium. This limitation can be overcome by using silver nanoparticles as an antimicrobial agent owing to the continuous release of $\mathrm{Ag}$ ions they provide (Kim et al., 2007).

\section{Modified water-soluble paint}

We impregnated water-soluble paints with our nanosized silver colloids. Most of the initial silver nanoparticles agglomerated into clusters up to $200 \mathrm{~nm}$ in size because of attractive interaction forces between them (Fig. 2). The photographs in Fig. 3 show the growth of A. pullulans, $P$. phoeniceum, and $S$. aureus cultures on pasteboard samples modified by silver nanoparticles. The test results of the antibacterial and antifungal effects of nanosilver-based water-soluble paint are summarized in Table 2, where the plus sign indicates the occurrence of microbial growth, and the minus sign corresponds to the absence of visible growth.

An increase in the concentration of nanosilver in water-soluble paint to $5-6 \mu \mathrm{g} / \mathrm{cm}^{2}$ led to the suppression of growth of B. subtilis and E. coli. Larger concentrations of nanosilver can potentially lead to undesirable color shifts in water-soluble paint with time. We observed an outside wall of a house painted (Tashkent, Uzbekistan) with nanosilver-modified $\left(0.8 \mu \mathrm{g} / \mathrm{cm}^{2}\right)$ paint. The NAA tests conducted over a period of eight months (April-November, 2018) showed that no significant loss of silver nanoparticles in the wall paint occurred (Garipov et al., 2019).

We suggest that silver nanoparticles may be a commercially viable addition for use in the paint industry. Microbes can come into contact with walls in a number of ways, including by deposition of dust and fine aerosols, by human skin contact, and by splashes from liquids.

Table 1. Results of minimum inhibitory concentration (MIC) assays for silver nanoparticles and silver ions for some microbial species

\begin{tabular}{|c|c|c|}
\hline Microbe species & $\begin{array}{c}\text { Electrically generated silver ion } \\
\text { MIC }(\mathrm{mg}(\mathrm{Ag}) / \mathrm{L})\end{array}$ & $\begin{array}{c}\text { Silver nanoparticle } \\
\text { (average particle size of } 7 \mathrm{~nm}) \\
\text { MIC }(\mathrm{mg}(\mathrm{Ag}) / \mathrm{L})\end{array}$ \\
\hline Escherichia coli & 1 & 5 \\
\hline Staphylococcus aureus & 0.6 & 3 \\
\hline Penicillium phoeniceum & 0.5 & 2 \\
\hline Bacillus subtilis & 2.4 & 29 \\
\hline
\end{tabular}




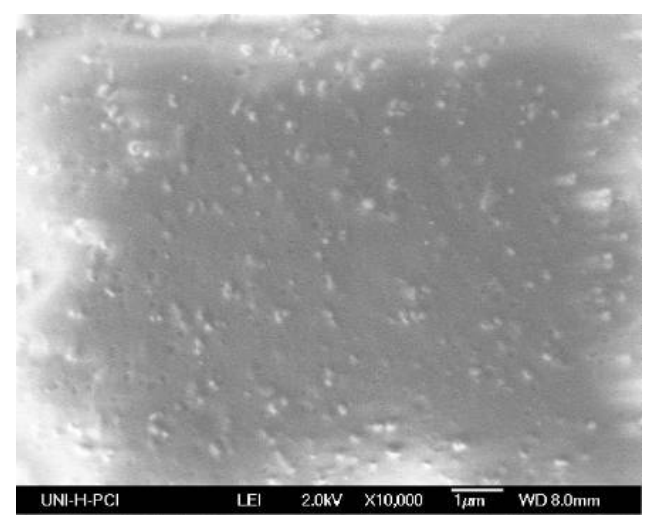

Fig. 2. A sample of water-soluble paint with immobilized silver nanoparticles
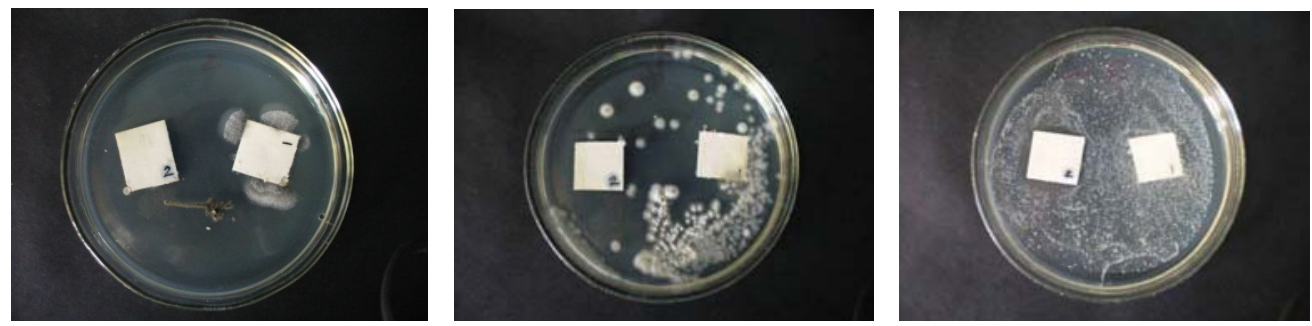

Fig. 3. Growth of A. pullulans (left), P. phoeniceum (middle), and S. aureus (right) cultures on pasteboard samples modified by silver nanoparticles (note, the white spots correspond to microbial colonies). Sample \#1 is a control sample, i.e., it was covered with nonmodified paint; sample \#2 was covered with the paint modified by silver nanoparticles at a density of $0.8 \mu \mathrm{g} / \mathrm{cm}^{2}$

Table 2. Antimicrobial effect of samples of water-soluble paint

\begin{tabular}{|c|c|c|}
\hline \multirow{2}{*}{ Microbe species } & \multicolumn{2}{|c|}{ Type of paint } \\
\cline { 2 - 3 } & $\begin{array}{c}\text { Sample \#1 } \\
\text { (Nontreated paint) }\end{array}$ & $\begin{array}{c}\text { Sample \#2 } \\
\left(\begin{array}{c}\text { Nanosilver-modified paint, } \\
\left.0.8 \mu \mathrm{g} / \mathrm{cm}^{2}\right)\end{array}\right.\end{array}$ \\
\hline Aspergillus niger & + & - \\
\hline Penicillium phoeniceum & + & - \\
\hline Aureobasidium pullulans & + & - \\
\hline Staphylococcus aureus & + & + \\
\hline Bacillus subtilis & + & + \\
\hline Escherichia coli & + & - \\
\hline Control (samples on beef-extract agar) & + & \\
\hline
\end{tabular}

Note: “+”- growth on beef-extract agar; “-“- absence of growth on beef-extract agar

Nanosilver-based wall paint can potentially prevent the formation of mold inside buildings and, by conjecture, the growth of algae on outside walls.

\section{Modified cotton fabric}

We also impregnated $100 \%$ cotton fabrics with nanosized silver colloids synthesized by the electrochemical technique (Khaydarov et 
al., 2009). The particles had reasonably good dispersibility on the surface of a modified cotton spread. However, agglomeration of silver nanoparticles into larger clusters (up to $200 \mathrm{~nm}$ in size) was also observed (Fig. 4).

As shown previously (Khaydarov et al., 2009a, 2010), a cotton fabric with immobilized silver nanoparticles (mean particle size of $15 \mathrm{~nm}$ ) with concentrations of $5 \mu \mathrm{g} / \mathrm{cm}^{2}, 3 \mu \mathrm{g} / \mathrm{cm}^{2}$, and $1 \mu \mathrm{g} / \mathrm{cm}^{2}$ can inhibit the growth of $A$. niger, $P$. phoeniceum, and $S$. aureus cultures, respectively, on beef extract agar. In the present study, we used an aqueous dispersion of $7 \pm 3 \mathrm{~nm}$ silver nanoparticles during the finishing process. This approach reduced the size of silver particles on the surface of the $100 \%$ cotton fabric from the micron size (as in our previous work) to $\sim 100 \mathrm{~nm}$. As a result, the antifungal/antibacterial effects for A. niger, P. phoeniceum, and S. aureus were confirmed for nanosilver concentrations on the surface of the cotton fabric as low as even $1 \mu \mathrm{g} / \mathrm{cm}^{2}$. The same experiments conducted for E. coli, B. subtilis, and A. pullulans cultures demonstrated a pronounced antimicrobial effect for concentrations of nanosilver of $7 \mu \mathrm{g} / \mathrm{cm}^{2}$, $5 \mu \mathrm{g} / \mathrm{cm}^{2}$, and $3 \mu \mathrm{g} / \mathrm{cm}^{2}$, respectively.

To estimate the durability of the bacteriostasis effect of the silver-treated cotton fabric with respect to laundering, we compared the surface concentration of silver particles on fabrics before washing to the particles on them after 2, 5, and 10 washes (Table 3). The results indicated that silver particles were sufficiently bonded to the cotton fabric, which gave rise to good bacteriostasis effects after even 10 cycles of washing. These findings are encouraging results

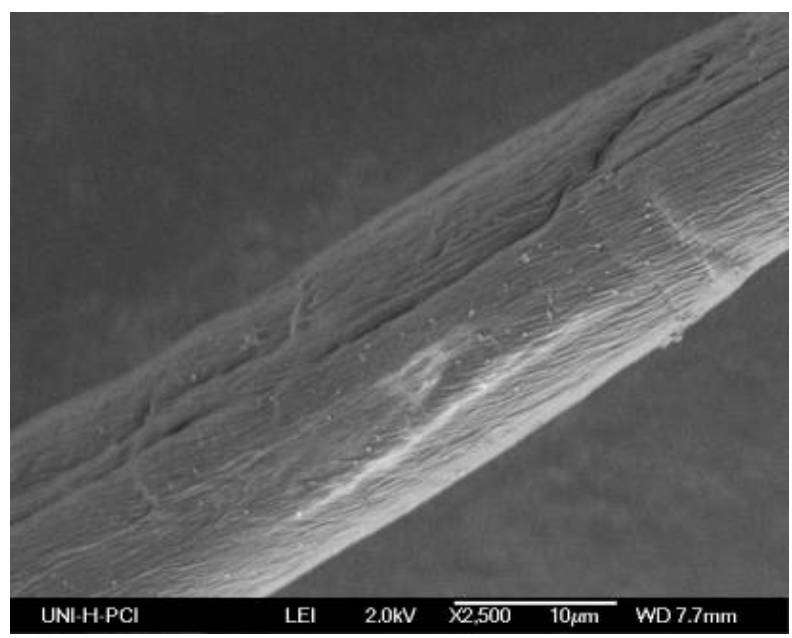

Fig. 4. A sample of $100 \%$ cotton with immobilized silver nanoparticles

Table 3. Laundering durability of silver nanoparticles on modified cotton fabric samples

\begin{tabular}{|c|c|}
\hline & Ag concentration $\left(\mu \mathrm{g} / \mathrm{cm}^{2}\right)$ \\
\hline Before washing & 5 \\
\hline After 2 cycles & 3.5 \\
\hline After 5 cycles & 1.8 \\
\hline After 10 cycles & 1 \\
\hline
\end{tabular}


suggesting that nanosilver-based textile materials give promise in various areas, for example, in the prevention of wound contamination with microorganisms, particularly fungi and bacteria, in hospitals.

\section{Silver nanoparticle-coated fibrous sorbent for water treatment}

Fibrous chemisorbents are widely used in the republics of the former USSR for treating industrial wastes to remove harmful substances, including heavy metals - lead, zinc, copper, iron and compounds containing chlorine, sulfate and chromate anions (Zverev, 2002). An advantage of the fibrous ion-exchange sorbents over resins is the high rate of the sorption process (approximately 100 times greater than that for resins) and small values of pressure drop of the sorbent layer for purified water (Khaydarov and Khaydarov, 2006).

Microorganisms can attach to the surface of fibrous sorbents during their operation as water treatment materials and grow into biofilms, i.e., the sorbents can act as a reservoir of pathogenic microorganisms and potentially can lead to the risk of infection. To prevent microbial growth and formation of a biofilm on the sorbents during their usage, we coated fibrous ion-exchange sorbents with silver nanoparticles. Nanosilver not only attaches to the surface of the sorbent but also penetrates and associates under the surface due to the specific surface characteristics of the fibers, which are known (Zverev, 2002) to have a large surface area and high porosity (Fig. 5).

Most of the initial silver nanoparticles agglomerated into clusters of up to $300 \mathrm{~nm}$ because of attractive interaction forces between them. Our microbiological studies clearly demonstrated that a $20 \mathrm{mg} / \mathrm{kg}$ silver concentration provided a reliable prevention of the growth of these microorganisms on the surface of the fibrous ionexchange sorbents (Khaydarov et al., 2019).

Microbiological tests conducted over the period of 60 days showed that there was no biofilm growth on the surface of a silver nanoparticlecoated fiber sorbent during its everyday operation as a household water treatment filter. NAA tests also indicated that nanosilver was sufficiently bonded to the fibers, as there was no significant loss of silver nanoparticles in the sorbent throughout that period (Khaydarov et al., 2019).

\section{Conclusions}

$\mathrm{Ag}$ nanoparticles synthesized using our 3-stage method based on electrochemical reduction of $\mathrm{Ag}^{+}$ions in distilled water were proven to be very promising as a new generation
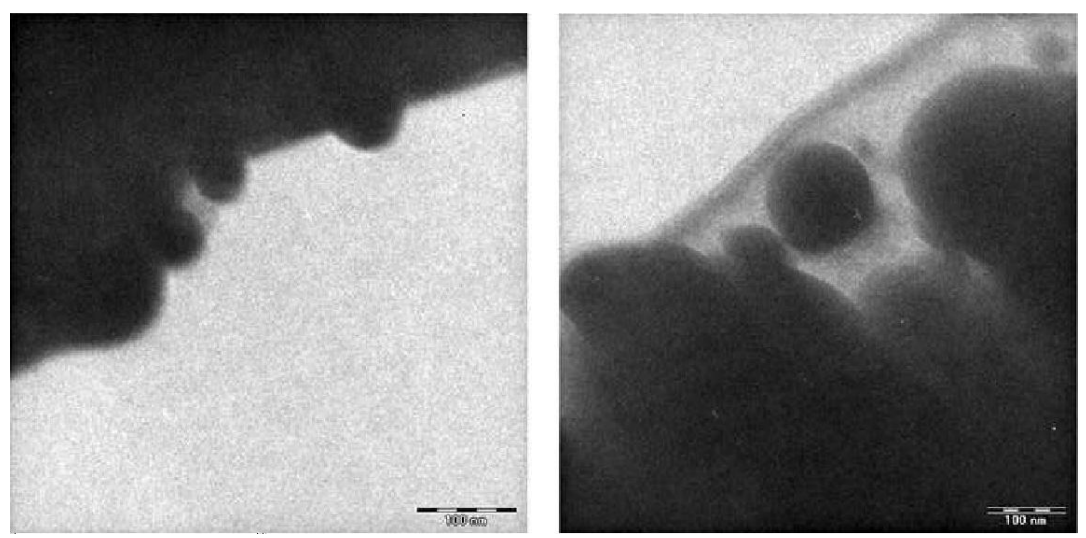

Fig. 5. A TEM image of silver nanoparticles on (left) and under (right) the surface of fibrous sorbent 
of antimicrobial agents. Our minimum inhibitory concentration tests quantitatively showed that $\mathrm{Ag}$ nanoparticles were less efficient against representatives of gram-positive/gram-negative bacteria and cosmopolitan saprotrophic fungi than $\mathrm{Ag}^{+}$ions. Because of the capability of $\mathrm{Ag}$ nanoparticles to continuously release $\mathrm{Ag}^{+}$ions in a sufficient concentration, they are considered a better option than $\mathrm{Ag}^{+}$ions in most antimicrobial applications. The tests carried out in the present study revealed that the obtained Ag nanoparticles as an add-on to water-soluble paints, textile fabrics or fiber chemisorbents had a remarkable antibacterial/antifungal effect, although some of the Ag nanoparticles were agglomerated into larger colloidal clusters.

\section{References}

Braydich-Stolle L., Hussain S., Schlager J., Hofmann M.C. (2005) In vitro cytotoxicity of nanoparticles in mammalian germline stem cells. Toxicological Sciences, 88(2): 412-419

Buzea C., Pacheco I.I., Robbie K. (2007) Nanomaterials and nanoparticles: Sources and toxicity. Biointerphases, 2(4): MR17-MR71

Chen C.Y., Chiang C.L. (2008) Preparation of cotton fibers with antibacterial silver nanoparticles. Materials Letters, 62(21-22): 3607-3609

Chen X., Schluesener H.J. (2008) Nanosilver: A nanoproduct in medical application. Toxicology Letters, 176(1): 1-12

Grodzik M., Sawosz E. (2006) The influence of silver nanoparticles on chicken embryo development and bursa of Fabricius morphology. Journal of Animal and Feed Sciences, 15 (Supplement 1): 111-114

Hussain S.M., Hess K.L., Gearhart J.M., Geiss K.T., Schlager J.J. (2005) In vitro toxicity of nanoparticles in BRL 3A rat liver cells. Toxicology in Vitro, 19(7): 975-983

Kim J.S., Kuk E., Yu K.N., Kim J.H., Park S.J., Lee H.J., Kim S.H., Park Y.K., Park Y.H., Hwang C.Y., Kim Y.K., Lee Y.S., Jeong D.H., Cho M.H. (2007) Antimicrobial effects of silver nanoparticles. Nanomedicine: Nanotechnology, Biology and Medicine, 3(1): 95- 101

Khalandi B., Asadi N., Milani M., Davaran S., Abadi A.J., Abasi E., Akbarzadeh A. (2017) A review on potential role of silver nanoparticles and possible mechanisms of their actions on bacteria. Drug Research, 67(2): 70-76

Khaydarov R.A., Khaydarov R.R., Olsen R.L., Rogers S.E. (2004) Water disinfection using electrolytically generated silver, copper and gold ions. Journal of Water Supply: Research and Technology-Aqua, 53(8): 567-572

Khaydarov R.A., Khaydarov R.R. (2006) Purification of drinking water from ${ }^{134,137} \mathrm{Cs},{ }^{89,90} \mathrm{Sr}$, ${ }^{60} \mathrm{Co}$ and ${ }^{129} \mathrm{I}$. Medical treatment of intoxication and decontamination of chemical agents in the area of terrorist attack. Dishovsky C. (ed.) Springer, Netherlands, p. 171-181

Khaydarov R.A., Khaydarov R.R., Gapurova O., Estrin Y., Scheper T. (2009) Electrochemical method of synthesis of silver nanoparticles. Journal of Nanoparticle Research, 11(5): 1193-1200

Khaydarov R.A., Khaydarov R.R., Estrin Y., Evgrafova S., Cho S., Scheper T., Endres C. (2009a) Silver nanoparticles: environmental and human health impacts. Nanomaterials: risk and benefits. Springer, Netherlands, p. 287-299

Khaydarov R.A., Khaydarov R.R., Gapurova O., Estrin Y. (2010) A novel method of continuous fabrication of aqueous dispersions of silver nanoparticles. International Journal of Nanoparticles, 3(1): $77-91$ 
Khaydarov R.R., Khaydarov R.A., Gapurova O., Garipov I., Lutfi Firdaus M. (2019) Silver nanoparticles as a biocide for water treatment applications. Advanced research in nanosciences for water technology. Nanotechnology in the life sciences. Prasad R., Karchiyappan T. (eds.) Springer, Cham, p. 407-419

Klasen H.J. (2000) Historical review of the use of silver in the treatment of burns. I. Early uses. Burns, 26(2): 117-130

Lee H.J., Jeong S.H. (2004) Bacteriostasis of nanosized colloidal silver on polyester nonwovens. Textile Research Journal, 74(5): 442-447

Lee H.J., Jeong S.H. (2005) Bacteriostasis and skin innoxiousness of nanosize silver colloids on textile fabrics. Textile Research Journal, 75(7): 551-556

Lewis L.N. (1993) Chemical catalysis by colloids and clusters. Chemical Reviews, 93(8): 26932730

Li Y., Wu Y., Ong B.S. (2005) Facile synthesis of silver nanoparticles useful for fabrication of high-conductivity elements for printed electronics. Journal of the American Chemical Society, 127(10): 3266-3267

Lok C.N., Ho C.M., Chen R., He Q.Y., Yu W.Y., Sun H., Tam P.K.H., Chiu J.F., Che C.M. (2007) Silver nanoparticles: partial oxidation and antibacterial activities. Journal of Biological Inorganic Chemistry, 12(4): 527-534

Marambio-Jones C., Hoek E.M.V. (2010) A review of the antibacterial effects of silver nanomaterials and potential implications for human health and the environment. Journal of Nanoparticle Research, 12(5): 1531-1551

Morones J.R., Elechiguerra J.L., Camacho A., Holt K., Kouri J.B., Ramirez J.T., Yacaman M.J. (2005) The bactericidal effect of silver nanoparticles. Nanotechnology, 16(10): 2346-2353

Murphy C.J., Sau T.K., Gole A.M., Orendorff C.J., Gao J., Gou L., Hunyadi S.E., Li T. (2005) Anisotropic metal nanoparticles: synthesis, assembly, and optical applications. Journal of Physical Chemistry B, 109(29): 13857-13870

Niemeyer C.M. (2001) Nanoparticles, proteins, and nucleic acids: biotechnology meets materials science. Angewandte Chemie - International Edition, 40(22): 4128-4158

Oberdorster G., Oberdorster E., Oberdorster J. (2005) Nanotoxicology: an emerging discipline evolving from studies of ultrafine particles. Environmental Health Perspectives, 113(7): 823-839

Soete D.D., Gijbels R., Hoste J. (1972) Neutron activation analysis. Wiley Interscience, New York

Soto K.F., Carrasco A., Powell T.G., Garza K.M., Murr L.E. (2005) Comparative in vitro cytotoxicity assessment of some manufactured nanoparticulate materials characterized by transmission electron microscopy. Journal of Nanoparticle Research, 7(2-3): 145-169

Wang Z., Xia T., Liu S. (2015) Mechanisms of nanosilver-induced toxicological effects: more attention should be paid to its sublethal effects. Nanoscale, 7(17): 7470-7481

Zverev M.P. (2002) Fibre chemisorbents - material for environmental protection. A review. Fibre Chemistry, 34(6): 456-465 